\title{
Inkompatibilitas Asas Pengaturan Sistem Pemilu dengan Sistem Pemerintahan Presidensial di Indonesia
}

\author{
Agus Riwanto \\ Fakultas Hukum Universitas Sebelas Maret Surakarta \\ Jl. Ir. Sutami No. 36 A Surakarta \\ agusriewanto@yahoo.com
}

\begin{abstract}
This study examines, first, whether the principles contained in the Electoral Act Norms are incompatible with the presidential system of government? Second, what is the cause of the incompatibility between the electoral system and the presidential system? Third, what are its influences in the practice of the implementation of presidential system of government which is based on the 1945 post-amendment? This study uses normative legal research (doctrinal) focusing on literature data. The study concluded that, first, the principles of the electoral system and the presidential system of government did not support each other as one integrated system. Second, the cause of incompatibility between these two systems was because the norms and provisions in the legislation governing the electoral systems of its principles were incompatible with the principles of presidential system of government. Third, the effect was not able to support the effectiveness of the course of the practice of the organization of presidential system of government which is based on the 1945 post-amendment.
\end{abstract}

Keywords: Incompatibility, principles, settings, election, and presidential

Abstrak

Penelitian ini mengkaji, pertama, apakah asas-asas yang terkandung dalam Undang-Undang Pemilu inkompatibel dengan sistem pemerintahan presidensial? Kedua, apa penyebab inkompatibilitas antara sistem pemilu dengan sistem presidensial? Ketiga, apakah pengaruhnya dalam praktek penyelenggaraan sistem pemerintahan presidensial berdasarkan UUD 1945 pasca amandemen? Penelitian ini menggunakan metode penelitian hukum normatif (doktrinal) memfokuskan pada data kepustakaan. Hasil penelitian menyimpulkan, pertama, asas-asas dalam sistem pemilu dan sistem pemerintahan presidensiil tidak saling menopang sebagai satu kesatuan sistem. Kedua, penyebab inkompatibalitas antara kedua sistem ini karena norma dan pasal-pasal di dalam undang-undang yang mengatur sistem pemilu asas-asasnya inkompatibel dengan prinsip-prinsip sistem pemerintahan presidensial. Ketiga, pengaruhnya tidak mampu menyokong efektifitas jalannya praktek penyelenggaraan sistem pemerintahan presidensial berdasarkan UUD 1945 pasca amandemen.

Kata Kunci: Inkompatibilitas, asas, pengaturan, pemilu dan presidensial 


\section{Pendahuluan}

Pemilihan Umum (Pemilu) adalah instrumen yang dapat "direkayasa" untuk melihat corak demokrasi, berjalannya sistem politik dan ketatanegaraan di suatu negara. Karena pemilu akan dapat membawa pengaruh pada tiga hal, yakni, sistem kepartaian, sistem pemerintahan, dan sistem perwakilan. Pendeknya, antara ketiganya adalah satu kesatuan sistem yang tak dapat dipisahkan.

Desain sistem pemilu di Indonesia pasca reformasi 1999, 2004, 2009 hingga 2014, terus mengalami perubahan dan perkembangan yang signifikan dengan dinamika kesejarahannya yang unik dan amat menarik untuk dicermati. Hal ini dapat dibuktikan melalui rutinitas pergantian paket undang-undang (UU) yang dipergunakan dalam setiap pemilu, bahkan antara pemilu sebelum dan sesudahnya tidak berkesinambungan. ${ }^{1}$

Perubahan paket UU Politik dalam setiap pemilu membuktikan, bahwa telah terjadi perubahan sosial-politik yang menuntut diakomodasi. Ini terjadi karena adanya pengaruh dan interaksi yang tak terelakkan dari masyarakat global. Dari aspek antropologi hukum, ini adalah implikasi dari mobilitas politik dan hukum karena bergeraknya sejumlah aktor baik orang, maupun organisasi yang bergerak dari satu negara ke negara lain. ${ }^{2}$

Penelitian ini difokuskan pada pemilu 2009 dengan mengkaji dan mendalami asas-asas melalui pasal-pasal dan ayat-ayat yang terkandung di dalam UU No. 10 Tahun 2008 tentang Pemilu Anggota DPR, DPD dan DPRD dan pengaruhnya terhadap sistem pemerintahan presidensial.

Mengkaji sebuah UU melalui asas-asasnya ini sangat penting, sebab asas hukum adalah merupakan "jantungnya" peraturan. Asas hukum merupakan landasan yang paling luas bagi lahirnya suatau peraturan. Jika ada persoalan dalam implementasi suatu peraturan, maka dikembalikan kepada asas-asasnya.

${ }^{1}$ Rekaman tentang proses dan kemajuan sistem dan hukum pemilu 1999 dengan sistem pemilu di masa Orde Baru dapat dibaca, Hermawan Sulistiyo, "Electoral Politics in Indonesia: A Hard Way to Democracy" in Electoral Politics in Southeast and East Asia Journal, Vol 51, No. 2, 1999, hlm. 77-100. Sedangkan perbandingan antara sistem pemilu 1999 dan 2004, ditulis secara cermat oleh Christopher J. Dagg, "The 2004 Elections in Indonesia: Political Reform and Democratisation” dalam Asia Pacific Viewpoint, Vol. 48, No. 1, April 2007, hlm. 47-59.

${ }^{2}$ Franz von Benda-Bechmann, Keebet von Benda Bechmann, dan Anne Griffiths, Mobile People, Mobile Law, Exspanding Legal Relations in Contracting World, England, Ashgate, 2005, hlm. 2-3. 
Karena itu asas hukum disebut sebagai alasan bagi lahirnya peraturan, atau merupakan ratio legis dari peraturan. ${ }^{3}$

Di lihat dari asas-asas yang terkandung di dalam UU ini dengan sistem pemerintahan presidensial bukan saja tidak harmonis, akan tetapi juga tidak saling menunjang sebagai sebuah sistem. Salah satu misal, dari aspek harmonisasi sistem pemilu, UU No. 10 Tahun 2008 mengandung beberapa kelemahan mendasar, karena UU ini menisbikan sebagian prinsip penggunaan sistem proporsional sebagaimana tercermin dalam Pasal 214 yang menentukan calon terpilih berdasarkan nomor urut. Namun, pengaturan tersebut berubah menjadi suara terbanyak, akibat dari dibatalkannya ketentuan Pasal 214 ini oleh Mahkamah Konstitusi (MK). ${ }^{4}$

UU No. 10 Tahun 2008 ini kerap diujikan ke MK karena berpotensi melahirkan ketidakadilan dalam berkompetisi. Padahal keadilan (justice) adalah merupakan esensi dan ruh dari hukum. ${ }^{5}$ Demokrasi harus memberi ruang kompetisi sama pada setiap individu dalam meraih jabatan politik. ${ }^{6}$ Pengujian UU ini dilakukan karena tidak sinkron dengan sistem pemilu secara keseluruhan dan dianggap bertentangan dengan filosofis dan asas dasar dalam Pasal 1 ayat (2) UUD NRI Tahun 1945, yakni kedaulatan berada di tangan rakyat yang dilaksanakan menurut Undang-Undang Dasar. Produk UU Pemilu sejatinya haruslah tidak mengandung problem filosofis merugikan hak dasar yaitu kedaulatan rakyat.

Bila ditelaah lebih dalam terdapat beberapa kelemahan dari UU No. 10 Tahun 2008: (1) kekosongan hukum; (2) ketidakkonsistenan hukum; (3) ketentuan multi-tafsir; dan (4) peraturan KPU yang juga tak tepat.7 Fenomena ini mendorong KPU harus bekerja keras menterjemahkan UU pemilu itu dalam aneka Peraturan KPU (PKPU) untuk menyelenggarakan pemilu yang demokratis.

${ }^{3}$ Satjipto Rahardjo, Imu Hukum, PT.Citra Aditya Bakti, Bandung, 2006, hlm. 45.

4 Lihat putusan Mahkamah Konstitusi (MK) Republik Indonesia No.22-24/PUU-VI/2008 tentang Pemilu Anggota DPR, DPD dan DPRD Berdasarkan Suara Terbanyak, 19 Desember 2008.

5 Todung Mulya Lubis, “Tidak Ada Artinya Hukum Tanpa Filsafat Hukum”, dalam Charles Himawan, 2006, Hukum Sebagai Panglima, PT Penerbit Buku Kompas, Jakarta, 2006, hlm. xxiv.

6 John Rawls, Theory of Justice, Harvard University Press, Cambridge, 1971.

7 Ramlan Surbakti, Perekayasaan Sistem Pemilu untuk Pembangunan Tata Politik Demokratis, Kemitraan Bagi Pembaruan Tata Pemerintahan di Indonesia (Partnership for Governance Reform Indonesia), Jakarta, 2008, hlm. 65-84. 
Proses pemilu (electoral process) 2009 menyisakan sejumlah persoalan yang dianggap mengurangi derajat demokrasinya, misalnya: terdapat lebih dari 40 juta pemilih yang tidak terdaftar di dalam Daftar Pemilih Tetap (DPT), sehingga mengurangi hak pilih warga, ini juga berarti mendorong golongan putih (golput) sistemik, ${ }^{8} \mathrm{KPU}$ tidak profesional karena sering merubah jadwal pemilu dengan mudah, melahirkan problem pada hampir semua tahapan pemilu: pendaftaran pemilih, pencalonan, kampanye, pemungutan suara, rekapitulasi suara, sampai penetapan calon terpilih ${ }^{9}$ dan borosnya penyelenggaraan pemilu menelan biaya Rp. 21.930.000.000.000,00.10

Pemilu 2009 nyaris kehilangan kepercayaan publik, karena tidak dapat memenuhi 10 (sepuluh) standar kriteria yang ditetapkan oleh ACE Electoral Knowladge Network: Inter-Parliamentary Union's Declaration on Free and Fair Election and Organisazion for Security and Co-operation in Europe's International Election Observation Standars. ${ }^{11}$

Berdasarkan asas dalam norma Pasal 6A, Pasal 7 dan 7C UUD NRI Tahun 1945, Indonesia menganut sistem pemerintahan presidensial yang prinsip dasarnya kekuasaan tertinggi pemerintahan ada di tangan presiden (consentration of power and responsibility upon the president). Namun, dalam prakteknya di era pemerintahan presiden SBY-JK periode 2004-2009 dan SBY-Boediono periode 2009-2014 terjadi ketidakcocokan (inkompatibel), karena sistem kepartaiannya adalah multipartai ekstrim dengan sistem pemilu proporsional berbasis suara terbanyak, maka DPR cenderung lebih tinggi kekuasaannya dari presiden.

DPR telah berkembang menjadi sangat kuat (superbody), sehingga kewenangan interpelasi telah beberapa kali digunakan. Inilah yang kerap terjadi pertunjukan antara presiden dan DPR bertarik ulur dalam adu kekuatan. Fungsi pengawasan yang dijalankan DPR mengarah pada kedaulatan parlemen. ${ }^{12}$

${ }^{8}$ Agus Riewanto, "Mengurai Problem Sistemik Daftar Pemilih Tetap Pemilu 2009”, Media Indonesia, 1 Mei 2009, hlm. 23 .

9 M. Hadi Shubhan, "Putusan MA Politicking", Jawa Pos, 31 Juli 2009, hlm, 5, dan Agus Riwanto, "Kenegarawanan Hakim MK dalam Mengadili Kinerja KPU”, Media Indonesia, tanggal 26 Juni 2009, hlm. 23.

10 "Mencari Sistem Pemilu yang Efektif dan efisien, Wawasan, 5 November 2010.

11 Adam Schmidt, “Indonesia's 2009 Election : Performance Challengers and Negative Precedent", in Edward Aspinall and Marcus Mietzner,(eds), Problems of Democratisation in Indonesia, Election, Institutions, and Society, ISEAS, Singapore, 2010, hlm. 109.

12 Hendardi, "Presidensial atau Parlementer", Kompas, 9 April 2008, hlm. 6. 
Akibatnya, praktek sistem pemerintahan presidensial berubah seolah-olah menjadi sistem pemerintahan parlementer. Sistem pemerintahan presidensial tidak dapat berjalan efektif dalam melaksanakan program kerja presiden karena waktunya lebih banyak untuk melakukan kompromi politik dengan DPR. Tekanan politik di DPR telah membuat presiden siapapun di Indonesia menjadi sangat rentan dan tidak independen dalam menjalankan kebijakan politiknya. ${ }^{13}$

\section{Rumusan Masalah}

Berdasarkan latar belakang yang diuraikan di atas, maka penelitian ini akan menjawab sejumlah masalah sebagai berikut: pertama, apakah asas-asas yang terkandung dalam norma undang-undang sistem pemilu tersebut inkompatibel dengan sistem pemerintahan presidensial. Kedua, apa penyebab inkompatibalitas antara sistem pemilu dengan sistem presidensial? Ketiga, apakah pengaruhnya dalam praktek penyelenggaraan sistem pemerintahan presidensial berdasarkan UUD NRI Tahun 1945?

\section{Tujuan Penelitian}

Adapun tujuan yang hendak dicapai melalui penelitian ini, pertama, menganalisis apakah asas-asas yang terkandung dalam norma UU Pemilu inkompatibel dengan sistem pemerintahan presidensial. Kedua, mengkaji dan menemukan penyebab inkompatibel antara sistem pemilu dengan sistem presidensial. Ketiga, menjelaskan tentang pengaruh inkompatibilitas antara asas pengaturan sistem pemilu dengan prinsip sistem pemerintahan presidensial dalam praktek penyelenggaraan sistem pemerintahan presidensial di Indonesia berdasarkan UUD NRI Tahun 1945.

13 Lihat, Andrew B. Withford and Soo- Young Lee, "The Efficiency And Inefficiency Of Democracy In Making Government Effective Cross National Evidence" Paper Presented at The Annual Meeting of American Political Science Assosiation, Toronto, Ontario, 23th September, 2008, hlm. 6. 


\section{Metode Penelitian}

Penelitian ini merupakan penelitian hukum normatif (doktrinal), yakni penelitian yang diterapkan khusus pada ilmu hukum. ${ }^{14}$ Hukum di sini diartikan, yaitu sebagai asas-asas kebenaran dan keadilan yang bersifat kodrati dan berlaku universal, ini merupakan karakteristik penalaran yang berorientasi filsafat. ${ }^{15}$

Pendekatan yang digunakan, yaitu asas-asas hukum, ${ }^{16}$ yakni menafsirkan kaidah-kaidah hukum dan asas-asas yang dirumuskan di dalam UU No. 10 Tahun 2008 tentang Pemilihan Umum Anggota DPR, DPD, DPRD Propinsi dan DPRD Kabupaten/Kota dan Pendekatan sistematik hukum, ${ }^{17}$ mengumpulkan unsur-unsur yang terorganisasi dan kerjasama ke arah tujuan kesatuan. Penelitian hukum normatif ini menggambarkan secara sistematis mengenai peraturan hukum dan fakta-fakta sebagai pelaksanaan peraturan perundang-undangan tersebut dalam prakteknya di lapangan. ${ }^{18}$

Penelitian ini memusatkan pada sumber bahan hukum kepustakaan atau dokumen (library research). Penelitian kepustakaan dimaksudkan untuk memperoleh data sekunder, berupa bahan hukum primer, sekunder dan tersier. Dilanjutkan dengan menginventarisir, meneliti atau menguji bahan-bahan hukum atau data tertulis yang relevan dengan objek penelitian. Dilakukan kritik data, penyusunan data sehingga hasilnya merupakan kesimpulan yang komprehensif, kritis dan evaluatif sebagai tahap preskripsi, sehingga menemukan hukum baru. Analisis secara integral-integratif, dapat dikonstruksikan dalam bentuk fakta, teori dan nilai. ${ }^{19}$ Penarikan kesimpulan dilakukan dalam bentuk uraian tulisan yang sistematis dan terarah.

${ }^{14}$ F. Sugeng Istanto, Penelitian Hukum, CV Ganda, Yogyakarta, 2007, hlm. 29.

15 Adi Sulistiyono, Mengembangkan Paradigma Non-Litigasi di Indonesia, Sebelas Maret University Press, Surakarta, 2007, hlm. 77-78.

16 Ruslan Saleh, Pembinaan Cita Hukum dan Asas-asas Hukum nasional, Karya Dunia Fikri, Jakarta, 1996, hlm. 5. Sudikno Mertokusumo, Penemuan Hukum:Sebuah Pengantar, Liberty, Yogyakarta, 1996, hlm. 5-6.

17 Sudikno Mertokusumo, Ibid., hlm. 5-6. Lihat juga Edie Toet Hendratno, Negara Kesatuan, Desentralisasi dan Federalisme, Graha Ilmu, Yogjakarta, 2009, hlm. 26, Satjipto Rahardjo, Op.Cit., hlm. 46-50.

18 Soerjono Soekanto, Pengantar Penelitian Hukum, UI-Press, Jakarta, 1984, hlm. 96.

19 Abdul Latif, Fungsi Mabkamah Konstitusi Upaya Mewujudkan Negara Hukum Demokrasi, Total Media, Yogyakarta, 2009, hlm. 47. 


\section{Hasil Penelitian dan Pembahasan}

\section{Prinsip Sistem Pemerintahan Presidensial Hanya Kompatibel dengan Sistem Model Dua Partai Politik}

Pada prinsipnya sistem pemerintahan presidensial tidak akan stabil jika dikombinasikan dengan sistem multipartai ekstrim. Seperti pernyataan Scott Mainwaring:"...But the combination of presidentialism and a fractionalized multi-party system seems especially inimical to stable democracy.."20 Pemerintahan stabil menurut Scott Mainwaring, adalah pemerintahan yang menjalankan prosedur demokrasi tanpa pernah terputus paling sedikit 25 Tahun. Ia menyatakan: “...stable (or continuos) democracy is defined here strietly on the basis of democratic longerity, more specifically, at least 25 years of uninterrupted democracy" ${ }^{21}$

Pengalaman praktek presidensial yang bersekutu dengan multipartai di Amerika Latin menunjukkan adanya sebuah realitas politik dalam hubungan kerja antara parlemen dan presiden dalam skema sistem presidensial yang tidak stabil, dimana terjadi presiden minoritas (minority president). Sebab presiden terpilih berasal bukan dari parpol pemenang mutlak dalam pemilu yang menyebabkan presiden tidak mendapatkan dukungan mayoritas di lembaga legislatif. Selain itu, juga adanya pemerintah yang terbelah (devided government), dimana sebagian dukungan politik ke presiden dan sebagian lain ke parlemen. Artinya sangat mungkin adanya dukungan politik parlemen yang tidak utuh dan loyal kepada presiden terpilih. ${ }^{22}$

Di dalam penelitiannya, Mainwaring juga menjelaskan dengan data empirik, bahwa ternyata hanya 4 negara dari 31 negara yang stabil menjalankan pemerintahannya dengan sistem pesidensial berbasis multipartai. Diantara negara-negara tersebut yang dapat terus stabil dengan sistem presidensial lebih dari 25 tahun hanyalah Amerika Serikat, Kolombia, Kostarika, Uruguay, dan Venezuela, namun dengan berbagai basis dwi partai (Dua Partai), dan hanya satu

\footnotetext{
${ }^{20}$ Scott Mainwaring, "Presidentialism in Latin Amerika", in Arend Lijphart (editors), Parliamentary Versus Presidential Government, Oxford University Press, 1992, hlm. 113.

21 Scott Mainwaring, "Presidentialism, Multipartism, and Democracy: The Difficult Combination", in Comparative Political Studies Journal, Vol, 26 No.2 July 1993, hlm. 204.

22 Scott Mainwaring and Matthew Sobergh Shugart, Presidensialism Democracy in Latin America, Cambridge University Press, 1997.
} 
negara yang berhasil mengawinkan sistem presidensial dengan multipartai, yakni Chile. Sedangkan 24 negara lainnya dapat stabil, karena menganut sistem parlementer dua negara (Finlandia, dan Prancis) menganut semi presidensial dan satu negara (Swiss) menganut sistem Hybrid. ${ }^{23}$

Sebab lain sistem presidensial tidak kompatibel dengan sistem multipartai adalah adanya "Dua-legitimacy" antara presiden dan legislatif yang sama-sama dipilih langsung oleh rakyat. Ini akan menyebabkan keduanya menjadi rivalitas yang tidak terobati ketika membahas kebijakan-kebijakan publik. ${ }^{24}$

Kombinasi presidensial dengan multi partai yang terfragmentasi dan terpolarisasi kepentingan ideologi dan kepentingan politik menjadi kian konfliktual antara presiden-parlemen, karena keputusan-keputusan publik yang akan dikerjakan presiden cenderung diwarnai oleh kompromi dan akomodasi kepentingan antara partai di parlemen yang berbeda dengan partai presiden.

Multipartai di parlemen cenderung membuat presiden melakukan koalisi antar partai-partai di parlemen terutama untuk memperkuat basis dukungan politik di parlemen. Sehingga kabinet presiden adalah kabinet pelangi. Secara teoritik koalisi hanya lazim terjadi dalam sistem parlementer. Karena watak parlementer adalah kompromi dan susunan kabinetnya adalah merupakan kombinasi dari partai-partai di parlemen. Sedangkan, watak sistem presidensial adalah kemandirian presiden (independent) dari parlemen, sehingga susunan kabinet presiden adalah kabinet yang loyal kepada presiden sebagai manifestasi dari pemusatan kekuasaan di tangan presiden (concentration at power upon the president atau the strong executive type of goverment). 25

Koalisi atau konsensual untuk pembentukan pemerintah dalam sistem, seperti dilakukan di Kolombia, namun koalisi dalam sistem presidensial jauh lebih sulit dibandingkan dengan sistem parlementer, karena: (Coalition or

\footnotetext{
${ }^{23}$ Scott Mainwaring, Presidensialism, Multipartism..., Op. Cit., 1993, hlm. 205.

${ }^{24}$ Juan Linz, "Presidentialism, and Democracy: A Critical Aprasial", in Comparative Politics, Vol. 29, No 4 July, 1997, hlm. 45.

25 Douglas V. Verney, "Parlementary Government And Presidential Government" in Arend Lijphard (eds), 1992, Palementary Versus Presidential Governement, Oxford University Press,1997, hlm. 31-47.
} 
consociational government is possible in presidential regimes, but it is considerable more difficult than in parliamentary regimes). ${ }^{26}$

Pertama, dalam sistem parlementer, ketika tidak ada partai mayoritas di parlemen, maka partai-partai menentukan atau memilih anggota kabinet dan perdana menteri, serta mereka tetap bertanggung jawab atas dukungan terhadap pemilih. Sementara itu dalam sistem presidensial, presiden memilih sendiri anggota kabinetnya yang boleh jadi berasal dari partai oposisi atau partainya sendiri dan kalangan profesional, implikasinya partai-partai tidak mempunyai komitmen dukungan terhadap presiden. ${ }^{27}$ Scott Mainwaring mengatakan: "..Parliamentary regimes require party coalitions for creating governments when no sigle obtains majority, which means most of the time in most parliamentary system. Presidential system rarely include such intitutionalized mechnism for establising coalition role..." 28

Kedua, dalam sistem presidensial karena presiden dalam pembentukan kabinetnya lebih cenderung mengakomodasi individu elite parpol. Maka konsekuensinya tidak ada jaminan partai-partai di parlemen akan mendukung presiden, sebab yang diakomodasi presiden secara kasat mata adalah kepentingan elit parpol, bukan kepentingan parpol secara keseluruhan. Di sini tampak perbedaan persepsi akomodasi presiden antara elite parpol dan parpol itu sendiri menjadi pemantik tak solidnya dukungan partai-partai di parlemen pada presiden. ${ }^{29}$ Dalam hal ini Scott Mainwaring mengatakan: “...The president can attempt to buy the support of individual politicians from opposition parties, but this option exists only if the parties malleable". ${ }^{30}$

Sesungguhnya koalisi dalam sistem presidensial seharusnya, bukan merupakan jalan utama untuk melakukan stabilitas sistem pemerintahannya, melainkan hanyalah langkah darurat yang ditempuh presiden. Karena itu koalisi hanyalah sebuah politik kreatif untuk mensiasati dalam menaklukkan lawan

\footnotetext{
26 Scott Mainwaring, "Presidentialism in Latin America" in Arend Lijphard (eds), Parlementary Versus Presidential Governement, Oxford University Press, 1992, hlm. 111-115.

27 Saldi Isra, "Pemilihan Presiden Langsung Dan Problematik Koalisi dalam Sistem Presidensial", dalam Jurnal Konstitusi, Vol. II, No. 1, Juni 2009, Mahkamah Konstitusi Bekerjasama dengan Pusat Studi Konstitusi (Pusako) FH Universitas Andalas, Jakarta, 2009, hlm. 123.

${ }^{28}$ Ibid., hlm. 115.

${ }^{29}$ Ibid., hlm. 123.

${ }^{30}$ Ibid., hlm. 115.
} 
politiknya. Dalam soal ini Juan J Linz berkomentar: "Coalitions are difficult to form and rarely, 'only exceptionally' do form under presidentialism". 31

Alasan lain ketidakharmonisan sistem presidensial dengan sistem multipartai di parlemen, adalah karena adanya keterpisahan secara tugas (separation of power) antara presiden dan parlemen dengan ditandai adanya pemilihan presiden dan pemilihan legislatif yang berbeda, sehingga berpotensi melahirkan jenis dukungan partai yang berbeda, sekaligus tidak paralel antara partai yang menguasai parlemen dan partai yang memenangkan pemilihan presiden dalam pemilu presiden. Keterpisahan politik antara keduanya akibat separation of power ini menyebabkan terjadinya hubungan yang kaku dan tidak fleksibel antara keduanya.

\section{Prinsip Sistem Pemerintahan Presidensial Hanya Kompatibel dengan Pelembagaan Sistem Kepartaian yang Kuat}

Perilaku aktor politik di DPR pasca reformasi, tidak terpola dengan jelas antara beroposisi atau mendukung kebijakan pemerintah. Padahal perilaku yang mempola, kelak menjadi sikap dan budaya, tentu akan mempermudah bagi pelaksanaan tugas-tugas DPR dalam hubungannya dengan presiden. Karena dengan perilaku partai yang mempola tidak mengalami fluktuasi dan standar ganda dalam melakukan pengawasan pada kinerja presiden. Sehingga mempermudah pula bagi presiden untuk menjalankan tugas penyelenggaraan pemerintahan tanpa diiringi oleh sikap-sikap reaktif dan oportunistik parlemen.

Apabila perilaku partai di parlemen mempola, maka akan cenderung melahirkan sikap disiplin dan konsisten pada partai. Misalnya, ketika parpol di parlemen bersikap sebagai oposisi, maka perilaku oposisi ini akan dipertahankan dalam bentuk budaya oposisi di parlemen, dalam semua isu dan kebijakan publik yang dijalankan presiden. Sebaliknya, jika sikap parpol di parlemen yang bersekutu dan mendukung pemerintah/presiden, maka sikap ini juga dipertahankan dalam kondisi apapun. Dengan kejalasan sikap ini akan melahirkan budaya politik yang demokratis, karena memperlihatkan fatsoen

${ }^{31}$ Lihat, Juan J.Linz, "Presidential or Parlementary Democracy: Does it Make a Difference ?, In Juan J.Linz and Aruto Venezuela (eds), The Failure of Presidential Democracy: The Case of Latin America, Baltimore, Md, John Hopkins, 1994, hlm. 19. 
(etika) politik, berupa konsistensi dan komitmen berpolitik. Model ini akan mengeliminir sikap pragmatisme parpol dan membentuk disiplin berpolitik. Terutama dalam mengusung program partai dan ideologi partai di parlemen. ${ }^{32}$

Chile adalah contoh negara yang menggabungkan sistem multipartai dengan sistem presidensial yang tidak bermasalah, bahkan cenderung stabil pemerintahannya. Salah satu faktor keberhasilannya adalah adanya kedisiplinan parpol di parlemen dalam mengusung ideologi dan program partai di parlemen, serta sikap politik yang konsisten dan penuh komitmen. ${ }^{33}$

Kedisiplinan parpol di parlemen menjadi kata kunci keberhasilan sistem presidensial maupun parlementer di hampir semua negara demokrasi di dunia, terutama dalam mempertahankan stabilitas pemerintah dan efektifitas pemerintah, apakah sistem itu dipadukan dengan multi partai atau dwi partai. Bahkan, ketika sistem parlementer telah disokong oleh dwi partai (partai pemerintah dan oposisi) yang secara teoretik akan lebih stabil dan efektif pemerintahannya, namun jika tidak disertai kedisiplinan parpol akan dapat melahirkan sistem pemerintahan yang tidak stabil.

Jika tujuan utama pemilihan sistem pemerintahan Indonesia pasca amandemen UUD 1945 adalah sistem presidensial murni yang efektif dan stabil pastilah berkeinginan adanya sistem pelembagaan parpol yang kuat di DPR, terutama adanya perilaku yang mempola dan dapat diwujudkan dalam sikap dan budaya politik. Dengan cara ini akan dapat melahirkan sikap politik yang konsisten dan meminimalkan politik yang pragmatis (untuk kepentingan jangka pendek).

Sebenarnya sistem pemerintahan presidensial versi UUD 1945 pasca amandemen tidak kompatibel dengan sistem pelembagaan parpol yang lemah, sebagaimana dituangkan dalam prinsip pengaturan sistem kepartaian dalam Undang-Undang No. 10 Tahun 2008 tentang pemilihan anggota DPR, DPD dan DPRD pada pemilu 2009.

32 Barry Ames and Timothy J Power, "Parties and Governability" dalam Paul Webb and Stephen White, (eds), Party Politics in New Democracies, Oxford, USA : Oxford University Press, 2009, sebagaimana di kutip oleh Ramlan Surbakti, 2010, “Sistem Pemilihan Umum Rentan Masalah” Kompas, 9 September 2009, hlm. 6.

${ }^{33}$ Scott Mainwaring, "Presidentialism, Multipartism...,"Op. Cit., 1993, hlm. 224. 
Pada puncaknya perilaku yang mempola dari parpol di parlemen, berupa kedisiplinan yang tinggi itu akan menentukan derajat kesistemannya, yaitu proses pelaksanaan fungsi-fungsi parpol, termasuk penyelesaian konflik, dilakukan menurut aturan, persyaratan prosedur, dan mekanisme yang disepakati dan ditetapkan dalam AD/ART parpol. Aturan dalam Anggaran Dasar dan Anggran Rumah Tangga (AD ART) itu harus demokratis sesuai asas kedaulatan partai, terletak di tangan anggota, juga perlu dirumuskan secara rinci sehingga mampu berfungsi sebagai kaidah dan prosedur penuntun perilaku dalam melaksanakan semua fungsi parpol. Karenanya parpol dapat dikatakan sudah melembaga dari segi kesisteman apabila parpol melaksanakan fungsi semata-mata menurut AD/ART yang demokratik dan dirumuskan secara komprehensif dan rinci tersebut. ${ }^{34}$

Sejauh ini kelemahan parpol di Indonesia belum ada kesisteman dalam partai yang ditandai dengan adanya 3 (tiga) hal: pertama, struktur organisasi partai yang sentralistik, kedua, kepemimpinan bersifat oligarki, yaitu dilakukannya oleh segelintir elit parpol, dan ketiga, kepentingan fraksi kelompok dan golongan lebih dominan daripada kepentingan partai sebagai organisasi. ${ }^{35}$

Isu-isu politik yang menyebabkan kelemahan sistem kepartaian Indonesia dapat dilihat dalam 3 (tiga) fenomena belakangan ini: pertama, penetuan pengurus parpol pada semua tingkatan. Kedua, penentuan calon dari parpol yang akan mengisi jabatan legislatif (DPR dan DPRD) dan ketiga, penentuan kebijakan parpol mengenai peraturan perundang-undangan dan kebijakan publik pada umumnya. Setidaknya tiga isu itu harus diputuskan melalui mekanisme rapat anggota sesuai dengan tingkatannya. Karena itu UU Partai Politik perlu memuat ketentuan yang mengharuskan setiap parpol merumuskan AD/ART secara komprehensif, setidaknya dalam tiga isu tersebut. 36

34 Ramlan Surbakti, "Perkembangan Parpol Indonesia" dalam Andy Ramses M, (eds), Politik dan Pemerintahan Indonesia, MIPI, Jakarta, 2009, hlm. 144-145.

35 Ibid.,hlm. 144.

36 Ibid., hlm. 45. 
Prinsip Sistem Pemerintahan Presidensial Hanya Kompatibel dengan Sistem Pemilu Mayoritas (Distrik).

Pada prinsipnya sistem pemilu proporsional secara teoretik dipastikan akan menghasilkan multi partai, karena sistem ini mula-mula dirancang untuk dapat mengakomodasi semua aspek heterogenitas dan kemajemukan politik dan berbagai kepentingan dalam masyarakat. Karena itu, kursi yang diperebutkan dalam pemilu melalui sistem ini selalu banyak (multi-member constituency).

Berbeda dengan sistem distrik (pluralitas-mayoritas), secara teoretik hanya akan menghasilkan sedikit partai, karena sistem ini dirancang untuk menciptakan sistem mayoritas dan tidak mengakomodasi minoritas. Disini prinsip pemenang mengambil semua (winner takes all) menjadi kata kunci dalam sistem ini, itulah sebabnya mengapa kursi yang disediakan dalam pemilu melalui sistem distrik ini hanya satu saja (single-member constituency).

Kedua sistem ini juga akan menghasilkan tipe demokrasi yang berbeda, sistem pemilu proporsional akan menghasilkan tipe demokrasi konsensus (concentual democracy), dimana aktor-aktor politik yang terlibat sangat banyak, beragam ideologi dan program saling ditawarkan melalui parpol, sebagai akibat adanya multipartai. Model demokrasi konsensus cenderung akan melahirkan fragmentasi dan polarisasi kepentingan yang beragam yang berpuncak pada berbelit-belitnya pengambilan setiap keputusan-keputusan publik dalam pemerintahan, karena berambisi untuk dapat mengakomodasi semua kepentingan aktor-aktor politik yang beragam itu. Akibat lain dari model demokrasi konsensus ini adalah cenderung berbiaya tinggi dan sering menimbulkan kegaduhan politik.

Sedangkan sistem pemilu distrik akan menghasilkan tipe demokrasi mayoritas (majoritarian democracy), dimana aktor yang terlibat dalam politik hanya 2 (dua) yang satu pemenang mutlak (winner takes all) berhak menguasai pemerintahan dan membentuk corak politik, dan yang lain sebagai aktor politik yang kalah tidak berhak menguasai pemerintahan apalagi membentuk corak politik, melainkan dipaksa oleh sistem untuk menjadi oposisi sistemik dengan pemerintahan. Tipe demokrasi ini cenderung tidak berbelit-belit dalam mengambil suatu kebijakan publik dalam pemerintahan, karena tidak perlu 
mengakomodir kepentingan politik dari aktor politik yang kalah. Akibat lainnya demokrasi tipe ini cenderung berbiaya murah dan tidak menimbulkan kegaduhan politik.

Kenyataan hadirnya dua tipe demokrasi: konsensus dan mayoritas, sebagai akibat dari konsekuensi pilihan sistem pemilu proporsional dan distrik sebagaimana dilukiskan oleh Arend Lijphart dengan pernyataan:37 "Two party system typify the majoritarian model of democracy and multiparty system the concescus model".

Prinsip dasarnya sistem pemerintahan presidensial akan efektif dan stabil apabila berada dalam perpaduan dengan tipe demokrasi mayoritas, karena cara ini akan mempermudah bagi presiden dalam mengeksekusi kebijakannya sebab didukung oleh partai mayoritas di parlemen dan jarang terjadi fragmentasi dan polarisasi di dalamnya. Sedangkan sistem pemerintahan parlementer dapat efektif justru ketika berpadu dengan multipartai karena adanya sharing kekuasaan antara sebagai aktor politik di dalam tubuh kabinet dan kabinet bertanggungjawab kepada parlemen. Karena itu, kabinet dapat diganti sewaktuwaktu bila tidak sejalan dengan parlemen. Sebaliknya sistem presidensial sulit mengganti presiden karena jabatan yang pasti (fixed term) kecuali ada pelanggaran-pelanggaran yang bersifat prinsip barulah presiden dapat dituntut mundur melalui jalur pemakzulan (impeachment). ${ }^{38}$

Sistem pemerintahan presidensial tidak akan efektif bila dikombinasikan dengan sistem Pemilu proporsional dengan varian opened list (terbuka), karena sistem ini akan menghasilkan konfigurasi politik di parlemen yang multipartai. Akan banyak sekali partai yang dapat hidup dan dapat mempunyai wakil di parlemen insentif bagi partai untuk menggabungkan diri partai minoritas sekalipun, sejauh melewati ambang batas (threshold), dapat survive secara politik.

Sistem pemerintahan presidensial akan stabil dan efektif bila dipadukan dengan tipe demokrasi mayoritas dan dengan sistem distrik, dimana cara ini akan dapat menghasilkan pemerintahan satu partai yang dapat mendominasi

37 Arend Lijphart, Pattern of Democracy, Government Form and Performance in Thirthy-Six Countries, Yale University Press, New Haven and London,1999, hlm. 63.

38 Aurel Croissant and Wolfgang Naerkel, "Political Party Formation in Presidential and Parliamentary System, in bttp://library-tes-de/pdf-files/gueros/philipinen/50072.pdf.Diakses pada tanggal 4 April 2011. 
eksekutif, jika seorang calon presiden terpilih, ia punya hak prerogatif untuk menentukan semua susunan kabinet, sang presiden tidak perlu berkompromi atau negosiasi dengan partai lain. Presiden dapat mengklaim, mayoritas rakyat sudah memberikannya hak penuh untuk memerintah.

Sebaliknya sistem pemerintahan parlementer pada prinsipnya akan kompatibel bila dikombinasikan dengan tipe demokrasi konsensus dan sistem pemilu proporsional. Sistem ini tidak akan melahirkan keberagaman politik sebagaimana tipe demokrasi majoritarian, karena demokrasi tipe ini dirancang untuk melahirkan pemerintahan koalisi. Dalam pemerintahan koalisi, semua segmen politik besar dan minoritas dianggap akan terwakili dalam pemerintahan.

Itulah maka pada prinsipnya sistem presidensial tidak akan berjalan stabil dan efektif bila dikombinasikan dengan sistem multipartai akibat dari pilihan sistem proporsional. Apabila jika presiden terpilih berasal dari partai minoritas yang tidak dapat menguasai parlemen. Maka yang akan terjadi adalah kesulitan presiden dalam memerintah, akibat tekanan politik oposisi partai mayoritas di parlemen yang berseberangan dengan presiden. Ini bukan hanya akan mengganggu stabilitas pemerintah juga berbahaya (peril) bagi demokrasi. ${ }^{39}$

Kepastian masa jabatan presiden (fixed term) presiden minoritas ini akan membuat sistem presidensial tidak adaptif terhadap perubahan, sehingga jika sewaktu-waktu terjadi kesalahan fatal dari presiden tidak dapat digantikan di tengah jalan. Inilah yang menyebabkan terjadinya potensi pergantian kekuasaan tidak melalui konstitusi (impeachment), melainkan melalui parlemen jalanan yang non-konstitusional. ${ }^{40}$ Dalam sistem presidensial, bahkan kerap kali ada kejadian dimana aktor-aktor non aktivis parpol berpotensi terpilih dalam pemilu untuk menduduki jabatan-jabatan eksekutif, menyebabkan mereka merasa tidak bergantung pada partai dan ini akan mengakibatkan hubungan yang disharmoni dengan parpol, lebih jauh Mattew Shugart menjelaskan:41

"..Political outsiders are more likely to win the chiet executive office in presidential system, with potentially destabilizing effects. Individuals elected by direct popular vote

${ }^{39}$ Juan J. Linz, "The Perils of Presidentialism" dalam Arend Lijphart (eds), Parlementary Versus Presidential Government, Oxford University Press, Oxford, 1992, hlm. 120. 450 .

40 Scott Mainwaring and Mattew Shugart, "Juan J.Linz, Presidential and Democracy.." Op. Cit., 1997, hlm.

${ }^{41} \quad$ Ibid., hlm. 451. 
are less dependent on and less beholden to political parties such individual are more likely to government in a populist, anti institutional fashion...".

Di lihat dari perjalanan sejarah ketatanegaraan Indonesia terutama pascaamandemen UUD 1945 dalam konteks relasi presiden dengan DPR dengan fokus pada pengaturan sistem kepartaian dan sistem pemilu sejak pemilu tahun 2004 dan tahun 2009, kita dipaksa untuk menyaksikan ketidak sinkronan dan ketidak konsistenan dalam menghubungkan antara sistem-sistem tersebut. Padahal berdasarkan aneka teks teoretik tentang demokrasi dengan penekanan pada pelembagaan politik (institutional design) selalu menganalisis sistem pemilu melalui (--UU pemilu--) dalam hubungannya dengan lembaga politik lain. ${ }^{42}$

Analisis dalam desain institusi politik (pelembagaan politik) yang kerap dijadikan pisau analisisnya adalah kombinasi sistem pemilu (proporsional atau distrik), karakter parpol (multipartai atau dwi partai), dan proses pemilihan pemerintahan eksekutif (presiden, presidensial atapun perdana menteri: parlementer), hubungan variabel makro itu, akan amat menentukan apakah demokrasi di sebuah negara stabil dan efektif atau sebaliknya mudah goyah, rapuh dan tidak efektif. ${ }^{43}$

Inkompatibilitas pengaturan sistem pemilu yang dihubungkan dengan sistem pemerintahan presidensial di Indonesia pasca amandemen UUD 1945 itu amat kentara. Fakta empiriknya dapat dilihat melalui praktek pemilu tahun 2004 dan 2009 yaitu :

Pertama, sistem kepartaian Indonesia menganut multipartai sederhana, namun diingkari oleh sistem pemilu yang menganut multipartai ekstrim, karena memilih sistem proporsional yang menyebabkan fragmentasi dan polarisasi partai-partai di DPR.

Kedua, sistem pemilihan presiden yang dilakukan secara langsung, calon diajukan oleh parpol atau koalisi antar parpol, yang menegaskan sistem presidensial, namun sistem ini tidak lazim, karena dikombinasikan dengan sistem

${ }^{42}$ Lihat, teori-teori yang mengeksplorasi sebab musabab adanya hubungan antara institusi politik seperti sistem pemilu dan parpol, serta stabilitas demokrasi. Geovanni Sartori, Parties and Party System, A Framework for Analysis, Cambridge University Press, Cambridge, 1976; Daouglas Rae, The Political Consequense at Electoral Laws, Yale University Press, New Haven, 1976; William H.Rieken, The Theory at Political Coalitions, Yale University Press, New Haven, 1962; and Rein Tagepera and Matthew Soberg Shugart, Seats and Votes, Yale University Press, New Haven, 1989.

${ }^{43}$ Danny J.A, "Konsekuensi Undang-Undang Politik", Kompas, 24 April 2002, hlm, 6. 
pemilu proporsional dan sistem kepartaian yang multipartai, akibatnya relasi presiden dan DPR terganggu dan tidak harmoni.

Faktor-faktor empirik ini menunjukkan sesungguhnya Indonesia tidak menganut kedua tipe demokrasi, baik majoritarian maupun consentual, tetapi Indonesia mengkombinasikan dua bentuk itu. Menjadi soal jika kita mengkombinasikan dua hal yang sulit dipadukan. Akibatnya yang dikombinasikan bukan hal yang terbaik dari keduanya, tetapi hal yang terburuk. Atau mengkombinasikan hal terbaik dari keduanya, namun tidak harmonis karena beda paradigma. Dilihat dari sistem pemilu melalui Undang-Undang No. 10 Tahun 2008 tentang Pemilihan Umum Anggota DPR, DPD dan DPRD dalam pemilu tahun 2009 dan konsekuensi politiknya, kita mengambil unsur tipe demokrasi konsensual, yaitu sistem pemilu proporsional. Akibat sistem pemilu ini adalah kita tetap akan mempunyai banyak partai (multipartai) tidak ada satu partai pun yang dapat mendominasi parlemen. ${ }^{4}$

Namun, dilihat dari pemilihan presiden melalui Undang-Undang No 42 Tahun 2008 tentang Pemilihan Umum presiden dan Wakil Presiden, kita menganut sistem demokrasi majoritarian karena mengadopsi sistem pemilihan berdasarkan prinsip mayoritas absolut (absolute majority), apabila telah diperoleh pasangan calon yang memperoleh suara lebih dari 50 persen akan ditetapkan sebagai presiden. ${ }^{45}$ Bila tidak tercapai maka dilanjutkan dengan pemilihan putaran kedua dengan prinsip mayoritas sederhana (simple majority) berapapun suara yang diperoleh akan langsung ditetapkan sebagai presiden dan wakil presiden. ${ }^{46}$ Dengan demikian, presiden yang kelak terpilih dapat mendominasi pemerintahan eksekutif sendirian. Presiden terpilih boleh dan mungkin dapat mengisi kabinet pemerintahannya hanya dari unsur partainya saja.

Tabel berikut akan menggambarkan inkompatibilitas antara sistem kepartaian multipartai, sistem pemilu proporsional dan tipe demokrasi serta konsekuensinya terhadap efektifitas dan stabilitas pemerintahan presidensial pasca amandemen UUD 1945:

\footnotetext{
${ }^{44}$ Danny J.A, Ibid., hlm. 6.

${ }^{45}$ Lihat, Pasal 6 ayat (3) UUD 1945 dan Pasal 159 ayat (1) Undang-Undang No. 4 Tahun 2008 tentang Pemilu Presiden dan Wakil Presiden.

46 Lihat, Pasal 6 ayat (4) UUD 1945 Pascaamandemen, dan Pasal 159 ayat (2) Undang-Undang No. 2 Tahun 2008 tentang Pemilu Presiden dan Wakil Presiden.
} 
Perbedaan Praktek Sistem Kepartaian, Pemilu, Pemerintah dan Implikasinya di Dunia

\begin{tabular}{|l|l|l|l|l|l|l|}
\hline \multicolumn{1}{|c|}{ Negara } & \multicolumn{1}{c|}{$\begin{array}{c}\text { Sistem } \\
\text { Pemilu }\end{array}$} & $\begin{array}{c}\text { Sistem } \\
\text { Kepartaian }\end{array}$ & $\begin{array}{c}\text { Kursi } \\
\text { Parlemen }\end{array}$ & $\begin{array}{c}\text { Tipe } \\
\text { Demokrasi }\end{array}$ & $\begin{array}{c}\text { Sistem } \\
\text { Pemerintah }\end{array}$ & Implikasi \\
\hline $\begin{array}{l}\text { Inggris Raya } \\
\text { (wesminster) }\end{array}$ & Proporsional & Multipartai & $\begin{array}{l}\text { Multi } \\
\text { Member } \\
\text { Constituen }\end{array}$ & Konsensus & $\begin{array}{l}\text { Parlementer } \\
\text { Koalisi } \\
\text { Dependent }\end{array}$ & Efektif \\
\hline $\begin{array}{l}\text { Amerika } \\
\text { Serikat }\end{array}$ & $\begin{array}{l}\text { Mayoritas- } \\
\text { Distrik }\end{array}$ & Dua Partai & $\begin{array}{l}\text { Single } \\
\text { Member } \\
\text { Constituen }\end{array}$ & Mayoritarian & $\begin{array}{l}\text { Presidensial } \\
\text { Non-Koalisi } \\
\text { Independent }\end{array}$ & Efektif \\
\hline Perancis & Proporsional & Multipartai & $\begin{array}{l}\text { Multi } \\
\text { Member } \\
\text { Constituen }\end{array}$ & Konsensus & $\begin{array}{l}\text { Campuran } \\
\text { Koalisi } \\
\text { Dependent }\end{array}$ & Efektif \\
\hline Indonesia & Proporsional & Multipartai & $\begin{array}{l}\text { Multi } \\
\text { Member } \\
\text { Constituen }\end{array}$ & Konsensus & $\begin{array}{l}\text { Presidensial } \\
\text { Koalisi } \\
\text { Dependent }\end{array}$ & Tidak \\
Efektif
\end{tabular}

Sumber: Diolah dari berbagai sumber.

Tabel di atas memperlihatkan, bahwa desain kelembagaan politik Indonesia tidak mengambil salah satu dari tiga model desain kelembagaan politik, yaitu: Inggris Raya (Wesminster), Amerika Serikat maupun Perancis, tetapi desain khas tersendiri. Kekhasan Indonesia itu justru menjadi kelemahannya, ketika berharap pada keinginan presidensial dan pemerintahan yang efektif. Padahal dapat dipastikan pilihan sistem pemerintahan presidensial di Indonesia melalui UUD 1945 pascamandemen adalah untuk menghasilkan pemerintahan yang efektif. Tidak akan dapat terwujud jika menggunakan sistem pemilu proporsional murni yang disproporsionalitas sebagaimana dipraktekkan dalam pemilu tahun 2009.

\section{Usulan Masa Depan}

Sistem pemerintahan presidensial hanya akan efektif bila dikombinasikan dengan sistem pemilu mayoritas atau distrik, sistem kepartaian menganut model dua partai yang satu berkuasa dan yang lain beroposisi, kursi parlemen diisi dengan model satu orang mewakili daerah dan partai tertentu, tipe demokrasinya mayoritas, sistem pemerintahannya presidensial tanpa koalisi dengan parpol yang kalah dalam pemilu sehingga presiden terpilih sangat mandiri dari tekanan 
politik di DPR dan implikasinya akan melahirkan sistem pemerintahan presidensial yang efektif. Sebagaimana tercermin melalui tabel berikut ini:

Desain Sistem Politik Ketatanegaraan Indonesia Masa Depan

\begin{tabular}{|c|c|c|c|c|c|c|}
\hline Negara & $\begin{array}{c}\text { Sistem } \\
\text { Pemilu }\end{array}$ & $\begin{array}{c}\text { Sistem } \\
\text { Kepartaian }\end{array}$ & $\begin{array}{c}\text { Kursi } \\
\text { Parlemen }\end{array}$ & $\begin{array}{c}\text { Tipe } \\
\text { Demokrasi }\end{array}$ & $\begin{array}{c}\text { Sistem } \\
\text { Pemerintah }\end{array}$ & Implikasi \\
\hline Indonesia & $\begin{array}{l}\text { Mayoritas } \\
\text { /Distrik }\end{array}$ & Dua Partai & $\begin{array}{l}\text { Single } \\
\text { Member } \\
\text { Constituent }\end{array}$ & Mayoritas & $\frac{\text { Presidensial }}{\frac{\text { Non-Koalisi }}{\text { Dependent }}}$ & Efektif \\
\hline
\end{tabular}

\section{Penutup}

Dari pembahasan di atas dapat disimpulkan. Pertama, asas-asas pengaturan sistem pemilu yang diatur dalam UU No.10 Tahun 2008 tentang Pemilu DPR, DPD dan DPRD, adalah (a) asas multi partai ekstrim; (b) asas melemahkan pelembagaan partai politik; dan (c) asas sistem pemilu proporsional yang disproporsional. Sedangkan prinsip-prinsip sistem pemerintahan presidensial, adalah (a) sistem presidensial hanya kompatibel dengan model sistem dua partai politik; (b) sistem presidensial hanya kompatibel dengan pelembagaan partai politik yang kuat; (c) sistem presidensial hanya kompatibel sistem pemilu mayoritas (Distrik). Dengan demikian norma pasal-pasal di dalam UU Pemilu asas-asasnya inkompatibel (tidak cocok) dengan prinsip-prinsip sistem presidensial. Kedua, secara filosofis kedua sistem ini tidak saling menopang sebagai satu kesatuan sistem, sehingga tidak tercapai harmonisasi antara maksud dan tujuan utama desain kedua sistem tersebut. Fenomena ketidakharmonisan kedua UU ini menunjukkan, bahwa para pembuat UU (DPR RI) telah gagal memenuhi asas filosofi dalam politik hukum legislasi. Ketiga, pengaruh inkompatibilitas (tidak cocok) asas-asas pengaturan sistem pemilu dengan prinsip-prinsip sistem pemerintahan dalam praktek penyelenggaraan sistem pemerintahan presidensial menurut UUD 1945 Pasca amandemen, ialah gagal menyokong terwujudnya efektifitas sistem pemerintahan presidensial. 


\section{Daftar Pustaka}

Antonio Cheibub, Jose, "Minority Government, Deadlock Situations and The Survival at Presidential Democracies", in Comparative Political Studies Journal, Vol.35 No.284, 2002.

---------,Cheibub, Jose, Adam Przeworski and Sebastian M.Saiegh, “Government Coalition and Legislative Success Under Presidentialism and Parlementarism", in British Journal of Political Science, No.34, 2004

Ames, Barry and J Power, Timothy "Parties and Governability" dalam Paul Webb and Stephen White, (eds), Party Politics in New Democracies, Oxford, USA : Oxford University Press, 2009.

Croissant, Aurel and Wolfgang, Naerkel, "Political Party Formation in Presidential and Parliamentary System, in http://ibrary-tes-de/pdffiles/gueros/philipinen/50072.pdf. Diakses pada tanggal 4 April 2011.

Hendardi, "Presidensial atau Parlementer", Kompas, 9 April 2008.

Hadi Shubhan, M, "Putusan MA Politicking", Jawa Pos, 31 Juli 2009

H.Rieken, William, The Theory at Political Coalitions, Yale University Press, New Haven, 1962

Isra, Saldi, "Pemilihan Presiden Langsung Dan Problematik Koalisi dalam Sistem Presidensial", dalam Jurnal Konstitusi, Vol. II, No. 1, Juni 2009, Mahkamah Konstitusi Bekerjasama dengan Pusat Studi Konstitusi (Pusako) FH Universitas Andalas, Jakarta, 2009

J.A, Danny, “Konsekuensi Undang-Undang Politik”, Kompas, 24 April 2002.

J. Dagg, Christopher, "The 2004 Elections in Indonesia: Political Reform and Democratisation" dalam Asia Pacific Viewpoint, Vol. 48, No. 1, April 2007.

Latif, Abdul, Fungsi Mahkamah Konstitusi Upaya Mewujudkan Negara Hukum Demokrasi, Total Media, Yogjakarta, 2009.

Linz, Juan J, "The Perils of Presidentialism" dalam Arend Lijphart (eds), 1992, Parlementary Versus Presidential Government, Oxford University Press, Oxford, 1992.

Juan J. "Presidential or Parlementary Democracy: Does it Make a Difference ?, In Juan J.Linz and Aruto Venezuela (eds), The Failure of Presidential Democracy: The Case of Latin America, Baltimore, Md : John Hopkins, 1994.

, Juan J, "Presidentialism, and Democracy: A Critical Aprasial", in Comparative Politics, Vol. 29, No 4 July, 1997.

Lijphart, Arend, Pattern of Democracy, Government Form and Performance in ThirthySix Countries, Yale University Press, New Haven and London, 1999.

Mulya Lubis, Todung, "Tidak Ada Artinya Hukum Tanpa Filsafat Hukum", dalam Charles Himawan, Hukum Sebagai Panglima, PT Penerbit Buku Kompas, Jakarta, 2006.

Mainwaring, Scott, "Presidentialism in Latin Amerika", in Arend Lijphart (editors), Parliamentary Versus Presidential Government, Oxford University Press, 1992. 
Scott, "Presidentialism, Multipartism, and Democracy: The Difficult Combination", in Comparative Political Studies Journal, Vol, 26 No.2 July 1993.

---------, Scott and Sobergh Shugart, Mattew, Presidensialism Democracy in Latin America, Cambridge University Press, 1997.

Mertokusumo, Sudikno, Penemuan Hukum:Sebuah Pengantar, Liberty, Yogjakarta, 1996.

Mencari Sistem Pemilu yang Efektif dan efisien, Wawasan, 5 November 2010.

Rae, Daouglas, The Political Consequense at Electoral Laws, Yale University Press, New Haven, 1976.

Rahardjo, Satjipto, Ilmu Hukum, PT.Citra Aditya Bakti, Bandung, 2006.

Rawls, John, Theory of Justice, Harvard University Press, Cambridge, 1971.

Riwanto, Agus, "Mengurai Problem Sistemik Daftar Pemilih Tetap Pemilu 2009", Media Indonesia, 1 Mei 2009.

--------, "Kenegarawanan Hakim MK dalam Mengadili Kinerja KPU", Media Indonesia, tanggal 26 Juni 2009.

--------, “Alergi Impeachment Presiden", Suara Merdeka, 28 Januari 20110.

Sulistiyo, Hermawan, "Electoral Politics in Indonesia: A Hard Way to Democracy" in Electoral Politics in Southeast and East Asia Journal,Vol 51, No.2, 2005.

Schmidt, Adam, "Indonesia's 2009 Election : Performance Challengers and Negative Precedent", in Edward Aspinall and Marcus Mietzner,(eds), Problems of Democratisation in Indonesia, Election, Institutions, and Society, ISEAS, Singapore, 2010.

Sugeng Istanto. F, Penelitian Hukum, CV Ganda, 2007, Yogjakarta.

Sulistiyono, Adi, Mengembangkan Paradigma Non-Litigasi di Indonesia, Sebelas Maret University Press, Surakarta, 2007.

Saleh, Ruslan, Pembinaan Cita Hukum dan Asas-asas Hukum nasional, Karya Dunia Fikri, Jakarta, 1996.

Soekanto, Soerjono, Pengantar Penelitian Hukum, UI-Press, Jakarta, 1984.

Stepan, Alfred and Skach, Cindy "Constitutional Framework and Democratic Consolidation Parlementarism Versus Presidentialism" in Journal of World Politics, Vol.46 No.1, 1993.

Subakti, Ramlan, Perekayasaan Sistem Pemilu untuk Pembangunan Tata Politik Demokratis, Partership Governance Reform Indonesia, Jakarta, 2008.

--------, "Perkembangan Parpol Indonesia" dalam Andy Ramses (editor), Politik dan Pemerintahan Indonesia, MIPI, Jakarta, 2009.

--------, Ramlan, "Sistem Pemilihan Umum Rentan Masalah", Kompas, 5 September, 2010.

Sartori, Giovanni, Parties and Party System, Canbrigde University Press, London, 1976.

Tagepera, Rein and Shugart Matthew Soberg, Seats and Votes, Yale University Press, New Haven, 1989.

Toet Hendratno, Edie, Negara Kesatuan, Desentralisasi dan Federalisme, Graha Ilmu, Yogjakarta, 1996 
V. Verney, Douglas, "Parlementary Government And Presidential Government" in Arend Lijphard (eds), 1992, Palementary Versus Presidential Governement, Oxford University Press, 1979.

von Benda-Bechmann, Franz, von Benda Bechmann, Keebet, dan Griffiths, Anne, Mobile People, Mobile Law, Exspanding Legal Relations in Contracting World, England, Ashgate, 2005.

Withford, Andrew B. and Lee Soo Young, "The Efficiency And Inefficiency Of Democracy In Making Government Effective Cross National Evidence" Paper Presented at The Annual Meeting of American Political Science Assosiation, Toronto, Ontario, 26th September, 2008.

Republik Indonesia, Undang-Undang Nomor 10 Tahun 2008 tentang Pemilihan Umum Anggota DPR, DPD, DPRD Propinsi dan DPRD Kabupaten/Kota

Republik Indonesia, Undang-Undang Nomor 2 Tahun 2008 tentang Partai Politik

Republik Indonesia, Undang-Undang Nomor 12 Tahun 2003 tentang Pemilihan Umum Anggota DPR, DPD, DPRD Propinsi dan DPRD Kabupaten/Kota.

Republik Indonesia, Undang-Undang Nomor 42 Tahun 2008 tentang Pemilihan Umum Presiden dan Wakil Presiden

Republik Indonesia, Undang-Undang Nomor 27 Tahun 2009 tentang MPR, DPD, DPR dan DPRD

Peraturan Komisi Pemilihan Umum No. 15 Tahun 2009 tentang Pedoman Teknis dan Pengumuman Hasil Pemilu, Tata Cara Penetapan Perolehan Kursi, Penetapan Calon Terpilih dan Pengganti Calon Terpilih Pemilu DPR, DPD, dan DPRD, Tanggal 16 Maret 2009.

Peraturan Komisi Pemilihan Umum No.149/SK/KPU/2008 tanggal 9 Juli 2008 tentang Penetapan Parpol Peserta Pemilihan Umum.

Peraturan Komisi Pemilihan Umum No.20 Tahun 2008 tentang Tahapan, Program, dan Jadwal Penyelenggaraan Pemilihan Umum Tahun 2009.

Putusan Mahkamah Konstitusi Republik Indonesia (MKRI) No.16/PUU-V/2007 Tanggal 23 Oktobe 2007 tentang Pemberlakukan Pasal 9 Ayat (1) dan (2) UU No. 12 Tahun 2003 tentang Pemilu Anggota DPR, DPD dan DPRD tidak Bertentangan dengan UUD 1945.

Sekretariat Jenderal DPR RI, 2007, Risalah Pendapat Akhir Fraksi-Fraksi DPR RI Dalam Pembicaraan Tingkat II/Pengambilan Keputusan terhadap Terhadap Rancangan Undang-undang Pemilihan Umum DPR, DPD dan DPRD, Setjen DPR RI, Jakarta. 